\title{
Catalase-negative, methicillin-resistant Staphylococcus aureus as a cause of septicemia
}

\author{
Staphylococcus aureus catalase-negativo resistente a meticilina como causa de septicemia
}

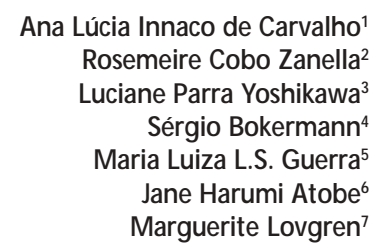

\section{key words abstract}

Catalase-negative

A catalase-negative methicillin-resistant Staphylococcus aureus (MRSA) was isolated from

Methicillin-resistant

blood, venous catheter spike and bone marrow collected from an HIV-positive man with

lobar pneumonia and sepsis after ten days of hospitalization. The isolate was resistant to

oxacillin (positive for penicillin-binding protein $2^{\prime}$ ), ceftriaxone, clindamycin and

clarithromycin, and susceptible to vancomycin. This is the first case of septicemia due to a

catalase-negative S. aureus reported in Brazil, and, to our knowledge, it is the first case of

catalase-negative MRSA reported in the literature. We believe that the patient acquired the $S$.

aureus infection within the hospital environment since it was isolated ten days after

hospitalization, it was isolated in a venous catheter spike, and the antibiotic resistance profile

is similar to other $\mathrm{S}$. aureus isolates recovered from infections in our hospital.

\section{resumo}

Em um paciente HIV-positivo, com pneumonia lobar e septicemia, foi isolada, após dez dias de internação, uma cepa de Staphylococcus aureus catalase-negativa, resistente a meticilina/ oxacilina (MRSA), de culturas de sangue, cateter venoso central e medula óssea. A cepa era resistente a oxacilina (PBP 2' positivo), ceftriaxona, clindamicina e claritromicina, e sensível a vancomicina. Este é o primeiro caso, reportado no Brasil, de uma septicemia por $\mathrm{S}$. aureus catalase-negativo e, em nosso conhecimento, o primeiro caso de um $\mathrm{S}$. aureus catalase-negativo resistente a meticilina. Nós a creditamos que o paciente tenha adquirido a infecção no ambiente hospitalar, uma vez que esta cepa foi isolada aos dez dias de internação, foi isolada em cateter venoso central e o perfil de sensibilidade aos antimicrobianos é semelhante ao dos $\mathrm{S}$. aureus de infecções nosocomiais que ocorrem em nosso hospital. unitermos

Catalase-negativo

Resistente a meticilina

1. Doutora em Patologia

médica da Seção de

Bacteriologia do Laboratório

de Patologia Clínica do

Instituto de Infectologia

Emilio Ribas, São Paulo, Brasil.

2. Doutora em Ciências,

pesquisadora do

Departamento de Bacteriologia

do Instituto Adolfo Lutz,

São Paulo, Brasil.

3. Estagiária da Seção de

Bacteriologia do Laboratório

de Patologia Clínica do

Instituto de Infectologia

Emilio Ribas, São Paulo, Brasil.

4. Assistente técnico de pesquisa

do Departamento de Bacteriologia

do Instituto Adolfo Lutz, São Paulo,

Brasil.

5. Assistente técnico de pesquisa

do Departamento de Bacteriologia

do Instituto Adolfo Lutz, São Paulo,

Brasil.

6. Mestre em Microbiologia; biologista

da Seção de Bacteriologia do

Laboratório de Patologia Clínica do

Instituto de Infectologia Emilio Ribas,

São Paulo, Brasil.

7. Technical supervisor, University of Alberta Hospital, National Centre for Streptococcus, Alberta, Canada.

Trabalho apresentado em forma de

painel no XXI Congresso Brasileiro de Microbiologia (2001), sob o seguinte

título: Staphylococcus aureus Catalase-

Negative Septicemia: First Case Reported in Brazil.

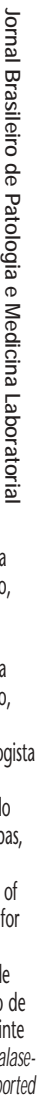
staphylococci is an uncommon event, clinical sulfatrimethoprim for Pneumocystis prophylaxis presented 
to the emergency care service of the Emílio Ribas Infectology Institute (IIER). He complained of fever, general myalgia, chest pain, and dyspnea. Lobar pneumonia was diagnosed and, because the patient also presented clinical signs of septicemia, he was hospitalized and treated with ceftriaxone, clarithromycin, and clindamycin. After a convulsive episode and loss of consciousness due to concomitant neurotoxoplasmosis, pyrimethamine and hydrocortisone therapies were also started. During his 11 days of hospitalization the neurological and septic conditions of the patient did not improve, and he eventually died.

\section{Bacteriology}

A blood culture drawn on the fourth day of hospitalization was negative, but cultures from blood, the venous catheter spike, and bone marrow, collected ten days after admission all grew gram-positive cocci. Opaque, yellow-pigmented, beta-haemolytic colonies of $1-2 \mathrm{~mm}$ in diameter were isolated on 5\% sheep blood agar, after aerobic incubation at $35^{\circ} \mathrm{C}$. The cellular morphology was typical of S. aureus, but the catalase was negative. The strain has not grown in anaerobic atmosphere.

The isolate was initially identified as $\mathrm{S}$. aureus at the Emílio Ribas Infectology Institute (IIER) lab, São Paulo, Brazil. This identification was obtained using the Vitek GPI card (biolab Merieux), but only when the catalase reaction was entered as positive rather than negative. Subsequently, it was referred to the Bacteriology Dept. of Adolfo Lutz Institute (IAL), São Paulo, Brazil, for confirmation by standardized biochemical testing (4) and for antibiotic susceptibility testing. The minimum inhibitory concentration (MIC) of the vancomycin was determined by E-test (AB-Biodisk, Solna, Sweden) according to the manufacturer's instructions and it was found to be susceptible to vancomycin (MIC $2 \mu \mathrm{g} / \mathrm{ml}$ ). The strain was resistant to oxacillin, ceftriaxone, clindamycin and clarithromycin by both disk diffusion (9) and the Vitek (ATB-GP card).

The strain was also referred to the National Centre for Streptococcus (NCS), Alberta, Canada, where the identification of catalase-negative $\mathrm{S}$. aureus was confirmed by conventional biochemical testing (6) and by cellular fatty acid analysis (Microbial ID, Inc, Newark, DE). The strain was also confirmed as methicillin-resistant by the detection of penicillin-binding protein 2' (PBP 2') using the MRSA screen ${ }^{\mathrm{TM}}$ test (Denka Seiken Co., Ltd., Tokyo, Japan). The low-affinity PBP in MRSA, termed PBP $2^{\prime}$ or
PBP 2a, is encoded by the chromossomal gene mecA (5) and is thought to function as a b-lactam-resistant transpeptidase.

The Table shows the phenotypic tests performed by the three labs which identified the strain.

\section{Discussion}

Members of the genus Staphylococcus are gram-positive cocci that are arranged in groups, or clusters, are nonmotile and do not produce spores. Staphylococci have a cell wall that is typical of all gram-positive bacteria and a $\mathrm{G}+\mathrm{C}$ content range of $30-40 \mathrm{~mol} \%$ (4). Most species are catalase-positive, except Staphylococcus saccharolyticus and Staphylococcus aureus subsp. anaerobius, which are catalase-negative and grow faster under anaerobic conditions (6). Staphylococcus aureus is routinely identified by its ability to produce coagulase, and a heat-stable nuclease but these characteristics are not limited to this species since $\mathrm{S}$. schleiferi, $\mathrm{S}$. hyicus and $\mathrm{S}$. intermedius may also be positive in both of these tests (4).

To this date, ten cases of infection due to catalasenegative Staphylococcus aureus have been published, eight of them in humans $(1,2,3,7,8,10,11,12)$. This is the first case of septicemia due to catalase-negative $S$. aureus reported in Brazil, and the fourth case that has been reported in the literature $(3,11,12)$. Furthermore, to our knowledge, it is the first published case of catalase-negative MRSA infection.

It is difficult to estimate the true incidence of catalasenegative Staphylococcus aureus strains that are recovered from clinical specimens because most bacteriology laboratories do not routinely perform the catalase test on coagulase-positive colonies with typical Staphylococcus aureus morphology. When these atypical strains are encountered, the porphyrin test is a useful additional identification tool (13). All members of Staphylococcus genus, including catalase-negative strains, will be porphyrin-positive.

We believe that the fatal outcome of this case was due to the patient's severe underlying clinical condition, immunodeficiency, and the continuation of inappropriate antibiotic therapy, which had been initiated to treat the original diagnosis of lobar pneumonia that was assumed to be caused by pneumococci or possibly by Mycoplasma.

It could be that the patient acquired the MRSA infection within the hospital environment through the central venous 


\section{Phenotypic characteristics of the catalase-negative, methicillin-resistant Staphylococcus}

Table aureus isolate described in this study

Test

Gram stain

Catalase

ALA

Slide coagulase

Tube coagulase

Heat-stable nuclease

Bacitracin

Novobiocin sensitivity

Voges Proskauer

Pyrrolydonylamidase

Nitrate reduction

Arginine

Ornithine

Urease

$40 \%$ bile growth

$10 \%$ bile growth

Esculin hydrolysis

Glucose

Arabinose

Cellobiose

Inulin

Lactose

Maltose

Mannitol

Mannose

Melezitose

Melobiose

Raffinose

Ribose

Salicin

Sorbitol

Sorbose

Sucrose

Trehalose

Xylose

Pyruvate

Indol production

DNAse

$\mathrm{NaCl} 6.5 \%$ growth

Peptone, glucose

Hemicellulase

Urea

Tetrazolium chloride

Pullulan
IIER*

Gram-positive

cocci in clamps

Negative

NP

NP

Positive

NP

Susceptible

Susceptible

NP

Negative

NP

Negative

$\mathrm{NP}$

NP

Negative

Positive

Negative

Acid

Negative

Negative

Negative

Negative

NP

Acid

Acid

Negative

Negative

Negative

Negative

Negative

Negative

NP

Acid

Acid

Negative

NP

NP

NP

Positive

Acid

Negative

Negative

Negative

Negative
IAL**

Gram-positive

cocci in clamps

Negative

Positive

NP

Positive

NP

NP

$N P$

NP

Negative

Positive

Positive

Negative

Positive

Negative

NP

NP

Acid

Negative

NP

NP

Acid

Acid

Acid

Acid

NP

NP

Negative

NP

NP

Negative

Negative

Acid

Acid

Negative

Negative

Negative

Positive

Positive

NP

NP

NP

NP

NP
NCS***

Gram-positive

cocci in clamps

Negative

Positive

Negative

Positive

Positive

Resistant

Susceptible

Positive: weak

Negative

Positive

Positive

Negative

Positive

NP

NP

Negative

NP

NP

Negative

NP

Acid

Acid

Acid

Acid

NP

NP

Negative

NP

NP

NP

NP

NP

Acid

Negative

NP

NP

NP

$N P$

NP

NP

NP

NP

NP

${ }^{*} \mid I E R$, Instituto de Infectologia Emílio Ribas; ${ }^{* *} \mid A L$, Instituto Adolfo Lutz; ${ }^{* *}$ NCS, National Centre for Streptococcus; NP, not performed. 
catheter, since the organism was isolated ten days after hospitalization, the previous blood culture, collected four days after he was admitted, was negative and it was also isolated in the venous catheter spike.

The antibiotic resistance profile shown for this $\mathrm{S}$. aureus strain is similar to other $\mathrm{S}$. aureus isolates recovered from infections in our hospital (data from the local hospital infection control service), suggesting that this was a nosocomially acquired infection. Further molecular analysis will be necessary to establish the clonal relatedness of this unusual MRSA isolate to others that have been recovered from this environment.
As noted by others $(1,12)$, the occurrence of catalasenegative $S$. aureus as an infective agent should be recognized, and clinical laboratories should be encouraged to include catalase testing in their $\mathrm{S}$. aureus identification protocols in order to collect more information about incidence and potential virulence of these unusual isolates.

\section{Acknowledgments}

We thank dr. Maria de Lourdes da Cunha from Universidade do Estado de São Paulo, Unesp-Botucatu, for her careful and thoughtful collaboration in the strain identification.

\section{References}

1.Al-A wagi,A . et al. C ellulitis due to catalase-negative Staphylococcus aureus. Infection, 24:54, 1996.

2. Carlson, J.R. \& Gorin, D.C. Case Report: Catalase-negative Staphylococcus aureus. Clin. Microbiol. Newslett., 3: 33-4, 1981.

3. C raw ford, P.A . et al. Septicaemia caused by a catalase-negative Staphylococcus aureus. J. H osp. Infect., 27: 320-2, 1994

4. Freney, J. et al. Recommended minimal standards for description of new staphylococcal species. Int.J. Syst. Bacteriol., 49:489502,1999

5.G eorgo papadakou, N .H .\& Smith, S.A. Penicillin-binding proteins in a Staphylococcus aureus strain resistant to specific $\beta$ lactam antibiotics. Antimicrob. Agents Chemother.,22: 172-5, 1982.

6. Kloos, W .E. \& Bannerman,T.E. Staphylococcus and M icrococcus. In: Murray P.R. et al. (ed) Manual of Clinical Microbiology. $7^{\text {th }}$ ed. A merican Society for Microbiology, W ashington, D.C. 1999.
7. Lee, $N$. et al. A case of carbuncle caused by a catalase-negative strain of Staphylococcus aureus. Diagn. M icrobiol. Infect. Dis, 24: 221-3, 1996.

8. Millar, M. et al. C atalase-negative Staphylococcus aureus. J. Clin. Pathol., 39: 695, 1986.

9. N ational Committee for Clinical Laboratory Standards. 2001. Performance standards for antimicrobial disk susceptibility testing; Eleventh Informational supplement. N CCLS document M100-S11.W ayne, PA.

10. N ice, C .S.C atalase-negative Staphylococcus aureus iso lated from a leg ulcer. J. H osp. Infect., 30: 159, 1995.

11. Tu, K.K. \& Palutke, W .A. Isolation and characterization of a catalase negative strain of Staphylococcus aureus. J. Clin. M icrobiol., 3: 77-8, 1976.

12. Turner, D.P.). et al. Catalase-negative Staphilococcus aureus septicaemia. J. Infect., 38: 132-5, 1999.

13. W ong, J.D. Porphyrin test as an alternative to benzidine test for detecting cytochromes in catalase-negative gram positive cocci. J. Clin. M icrobiol, 25: 2006-7, 1987.

\section{Correspondence to}

Ana Lúcia Innaco de Carvalho Avenida Dr. Arnaldo 165/1ªndar Laboratório Clínico CEP 01246-900 - São Paulo-SP Tel.: (+ 55 11) 3896-1200

e- mail: analuic@uol.com 